\title{
Comparison of Central Corneal Thickness Measurements by Ultrasonic Pachymetry, Orbscan II, and SP3000P in Eyes with Glaucoma or Glaucoma Suspect
}

\author{
Tsung-Ho Ou, MD; Ing-Chou Lai, MD; Mei-Ching Teng, MD \\ Background: Intraocular pressure (IOP) measurements are affected by the central cornea \\ thickness (CCT). The conventional method for CCT measurement is ultra- \\ sonic pachymetry. However, noncontact procedures lower the risk of infec- \\ tion and corneal damage. In this study, we compared the CCT measured by \\ Orbscan II, SP3000P, and ultrasonic pachymetry in patients with glaucoma \\ or glaucoma suspect. \\ Methods: The CCT of 208 eyes (46 eyes with glaucoma suspect, 42 with primary \\ angle-closure glaucoma, and 120 with primary open-angle glaucoma) was \\ measured using Orbscan II, SP3000P, and ultrasonic pachymetry. We com- \\ pared the linear correlation of the CCT between each mode. \\ Results: $\quad$ The mean CCT measured by Orbscan II $(563.63 \pm 35.867 \mu \mathrm{m})$ was larger \\ than with the other two devices. There were significant linear correlations \\ between measurements with ultrasonic pachymetry and Orbscan II (Pearson \\ correlation coefficient $(\mathrm{r})=0.793, p<0.001)$, ultrasonic pachymetry and \\ SP3000P $(\mathrm{r}=0.890, p<0.001)$, and Orbscan II and SP3000P $(\mathrm{r}=0.803, p<$ \\ $0.001)$. We divided the participants into 3 groups on the basis of the CCT \\ measured with ultrasonic pachymetry: $\leq 500 \mu \mathrm{m},>500 \mu \mathrm{m}$ to $\leq 578 \mu \mathrm{m}$, and \\ $>578 \mu \mathrm{m}$. There was no significant linear correlation between ultrasonic \\ pachymetry and Orbscan II in the thin group. But, in the intermediate and \\ thick CCT groups, there were significant linear correlations between each of \\ the three devices. \\ Conclusion: We showed good linear correlations of CCT measurements between each of \\ 3 devices, especially in the intermediate and thickest CCTs. These results \\ will be helpful in predicting the relationship between IOP and CCT for the \\ diagnosis and screening of glaucoma; even we used optic systems.
}

(Chang Gung Med J 2012;35:255-62)

Key words: central corneal thickness, ultrasonic pachymetry, orbscan II, SP3000P, glaucoma

$\mathrm{M}$ easurement of the corneal thickness is very important for the screening, diagnosis, and management of glaucoma. ${ }^{(1)}$ The central corneal thickness (CCT) significantly affects intraocular pressure (IOP) measured by Goldmann applanation tonometry. ${ }^{(2)}$ Several studies have shown that the

From the Department of Ophthalmology, Kaohsiung Chang Gung Memorial Hospital and Chang Gung University College of Medicine, Kaohsiung, Taiwan.

Received: Feb. 10, 2011; Accepted: Dec. 7, 2011

Correspondence to: Dr. Ing-Chou Lai, Department of Ophthalmology, Kaohsiung Chang Gung Memorial Hospital. No. 123, Dapi Rd., Niaosong Dist., Kaohsiung City 833, Taiwan (R.O.C.) Tel: 886-7-7317123 ext. 2801; Fax: 886-7-7352775;

E-mail: lai1@cgmh.org.tw 
measured IOP is lower than the actual IOP in thin corneas. ${ }^{(3,4)}$ An increased CCT may result in an artificially high IOP measurement, while a decreased CCT result in an artificially low IOP measurement. As a rough guide using an overview of published studies, it can be estimated that for every $10 \mu \mathrm{m}$ difference in the CCT from the population mean (approximately $542 \mu \mathrm{m}$ ), there is a $0.5 \mathrm{~mm} \mathrm{Hg}$ difference between the actual IOP and the IOP measured with Goldmann applanation tonometry. ${ }^{(5)}$ The Ocular Hypertension Treatment Study showed that people with low CCT values are at a high risk of developing primary open-angle glaucoma-up to a $70 \%$ increase in risk with a decrease of $40 \mu \mathrm{m}$ in $\mathrm{CCT}^{(4,6)}$ Another study indicated that both the corneal thickness and biomechanical properties influence the diagnosis and progress of glaucoma. ${ }^{(7-10)}$

Currently, ultrasonic pachymetry is a widely used technique to evaluate corneal thickness; however, direct placement of the probe onto the cornea may increase the risk of infection and damage to the corneal epithelium. Topical anesthesia is required, and it may influence the CCT measurements; furthermore, the examiner's experience can also influence the reliability of measurements.

Recently, noncontact pachymetry instruments such as Orbscan II (Bausch \& Lomb, Rochester, NY, U.S.A.) and SP3000P (Topcon Corp., Tokyo, Japan) have been developed. Orbscan II scanning slit topography has multiple applications in corneal examination, including thickness profile, anterior and posterior topography, elevation, and anterior chamber depth. ${ }^{(11-15)}$ SP3000P specular microscope is a noncontact optical instrument that also facilitates simultaneous pachymetric measurements. ${ }^{(16-19)}$

Several studies have compared corneal thickness measured by ultrasonic pachymetry, scanning slit topography, and specular microscopy by assessing the CCT measurement in healthy subjects, patients after refractive surgery, and patients with keratoconus. ${ }^{(11,16-21)}$ However, to the best of our knowledge, no study has conducted this comparison analysis with these 3 devices in glaucoma patients. In this study, we compared the CCT values measured by Orbscan II, SP3000P non-contact specular microscopy, and ultrasonic pachymetry (Ocuscan, Alcon, Texas, U.S.A.) in a population comprising patients with glaucoma suspect, primary open-angle glaucoma and primary angle-closure glaucoma.

\section{METHODS}

This study is a retrospective study. We reviewed patients who received CCT measurements with Orbscan II, SP3000P, and ultrasonic pachymetry from January, 2008 to July, 2010. This study was approved by the Institutional Review Board of Chang Gung Memorial Hospital (No.: 99-2479B).

The CCT of 208 eyes of 104 patients (46 eyes with glaucoma suspect, 42 with primary angle-closure glaucoma, and 120 with primary open-angle glaucoma) was measured using Orbscan II (acoustic factor $=0.935$ ), SP3000P, and ultrasonic pachymetry. We compared the linear correlation of the CCT between each mode of measurement.

The IOP measured by Goldmann applanation tonometry of all participants was under $21 \mathrm{~mm} \mathrm{Hg}$ when the CCT was measured. Moreover, none of the participants had undergone refractive surgery or intraocular surgery prior to the study; only the primary angle-closure glaucoma patients had received laser iridectomy. In order to ensure that the optic devices were not influenced by corneal clarity, corneal conditions were clarified by slit lamp examination.

First, we measured CCT with Orbscan II. The patient's chin was placed on the chin rest, and a blinking light was used as the fixation target. Corneal thickness within a central 3-mm area was recorded as the CCT measurement. Next, SP3000P was used to measure the corneal thickness and endothelium biometry parameters, but only CCT readings were used. Finally, after topical anesthesia with proparacaine hydrochloride ophthalmic solution (Alcaine, Alcon, Puurs, Belgium), 10 consecutive measurements with ultrasonic pachymetry were performed by an experienced technician, and the median of these 10 measurements was used as the CCT reading.

\section{RESULTS}

In this study, we examined both eyes of 104 patients-42 women and 62 men. The mean [standard deviation (SD)] age was 56.29 (13.21) years in women, 55.28 (13.68) years in men, and 55.87 (13.46) in the entire group.

We compared CCT values measured with the 3 devices, and the correlation between each test was evaluated. The value obtained with ultrasonic 
pachymetry [539.55 (SD, 38.113) $\mu \mathrm{m}$ ] was significantly lower than that measured with Orbscan II [563.63 (SD, 35.867) $\mu \mathrm{m}$ ] (paired $t$-test, $p<0.001$ ), but significantly higher than that measured with SP3000P [520.32 (SD, 35.179) $\mu \mathrm{m}$ ] (paired $t$-test, $p$ $<0.001$ ). These data are presented in Tables 1 and 2 .

There were significant linear correlations between measurements with ultrasonic pachymetry and Orbscan II (Pearson correlation coefficient $(\mathrm{r})=$ $0.793, p<0.001$; Fig. 1), ultrasonic pachymetry and SP3000P ( $r=0.890, p<0.001$; Fig. 2), and Orbscan II and SP3000P ( $\mathrm{r}=0.803, p<0.001$; Fig. 3$)$.

We divided the participants into 3 groups on the basis of the CCT measured with ultrasonic pachymetry: $\leq 500 \mu \mathrm{m},>500 \mu \mathrm{m}$ to $\leq 578 \mu \mathrm{m}$, and $>578 \mu \mathrm{m}$ (mean $\pm 1 \mathrm{SD}$ ). We also compared the mean CCT and correlations between each of the 2 devices in these 3 groups. In the thin CCT group, the linear correlations were low between ultrasonic pachymetry and SP3000P $(\mathrm{r}=0.369, p=0.021)$ and between Orbscan II and SP3000P ( $\mathrm{r}=0459, p=0.003)$. However, there were no significant linear correlations between ultrasonic pachymetry and Orbscan II $(\mathrm{r}=0.139, p=0.4)$. In the intermediate and thick CCT groups, there were significant linear correlations between each of the devices. These data are shown in Tables 1 to 3 .

\section{DISCUSSION}

The Barbados Eye Survey reported that black participants had thinner corneas (mean thickness, $529.8 \mu \mathrm{m})$ than white participants $(545 \mu \mathrm{m}) .^{(22)}$ Shimmyo et al. also showed that, in a population

Table 1. Mean Central Corneal Thickness Measurements

\begin{tabular}{|c|c|c|c|c|}
\hline & \multicolumn{4}{|c|}{ Mean $\pm \mathrm{SD}(\mu \mathrm{m})$} \\
\hline & $\begin{array}{c}\text { Total } \\
(\mathrm{n}=208)\end{array}$ & $\begin{array}{l}\text { Thin CCT group } \\
\qquad(\mathrm{n}=39)\end{array}$ & $\begin{array}{l}\text { Intermediate CCT group } \\
\qquad(\mathrm{n}=141)\end{array}$ & $\begin{array}{l}\text { Thick CCT group } \\
\qquad(\mathrm{n}=28)\end{array}$ \\
\hline US & $539.55 \pm 38.11$ & $489.26 \pm 7.73$ & $540.80 \pm 21.60$ & $603.29 \pm 27.56$ \\
\hline Orbscan II & $563.63 \pm 35.87$ & $531.26 \pm 26.61$ & $562.81 \pm 27.32$ & $612.82 \pm 31.15$ \\
\hline SP3000P & $520.32 \pm 35.18$ & $479.44 \pm 14.91$ & $521.11 \pm 23.61$ & $573.29 \pm 30.94$ \\
\hline
\end{tabular}

Abbreviations: US: ultrasonic pachymetry; CCT: central corneal thickness.

Groups were determined on the basis of the CCT measured by ultrasonic pachymetry as follows: Thin CCT group: $\leq 500 \mu \mathrm{m}$; Intemediate CCT group: $>500 \mu \mathrm{m}$ to $\leq 578 \mu \mathrm{m}$; Thick CCT group: $>578 \mu \mathrm{m}$.

Table 2. Differences in Central Corneal Thickness Measurements between Each Two Instruments

\begin{tabular}{|c|c|c|c|c|c|c|c|c|c|c|c|c|}
\hline & & $\begin{array}{c}\text { Total } \\
(\mathrm{n}=208)\end{array}$ & & & $\begin{array}{l}\text { n CCT gro } \\
(\mathrm{n}=39)\end{array}$ & & Interme & $\begin{array}{l}\text { diate CCT } \\
(\mathrm{n}=141)\end{array}$ & T group & Thick & $\begin{array}{l}\mathrm{k} \text { CCT g } \\
(\mathrm{n}=28)\end{array}$ & group \\
\hline & & $\begin{array}{l}95 \% \mathrm{CI} \\
\text { the differe }\end{array}$ & ence & of th & $\begin{array}{l}95 \% \mathrm{CI} \\
\text { he differen }\end{array}$ & nce & of $t$ & $\begin{array}{l}95 \% \mathrm{CI} \\
\text { he differen }\end{array}$ & ence & of th & $\begin{array}{l}95 \% \mathrm{CI} \\
\text { ne differe }\end{array}$ & ence \\
\hline & Lower & Upper & Sig. ${ }^{\dagger}$ & Lower & Upper & Sig. ${ }^{\dagger}$ & Lower & Upper & Sig. ${ }^{\dagger}$ & Lower & Upper & Sig. ${ }^{\dagger}$ \\
\hline US-Orbsc & -27.343 & -20.811 & $p<0.001$ & -50.641 & -33.359 & $p<0.001$ & -25.612 & $-18.402 I$ & $p<0.001$ & -15.546 & -3.525 & $p<0.001$ \\
\hline US- SP3000P & 16.844 & 21.617 & $p<0.001$ & 5.271 & 14.370 & $p<0.001$ & 16.807 & $22.583 r$ & $p<0.001$ & 23.864 & 36.136 & $p<0.001$ \\
\hline Orbscan II- SP3000P & 40.256 & 46.359 & $p<0.001$ & 44.108 & 59.533 & $p<0.001$ & 37.842 & $45.563 I$ & $p<0.001$ & 35.609 & 43.463 & $p<0.001$ \\
\hline
\end{tabular}

Abbreviations: US: ultrasonic pachymetry; CCT: central corneal thickness; CI: confidence interval; $\uparrow$ : Paired $t$ test, 2 tailed.

Groups were determined on the basis of the CCT measured by ultrasonic pachymetry as follows: Thin CCT group: > 500 $\mu \mathrm{m}$; Intemediate CCT group: $>500 \mu \mathrm{m}$ to $\leq 578 \mu \mathrm{m}$; Thick CCT group: $>578 \mu \mathrm{m}$. 


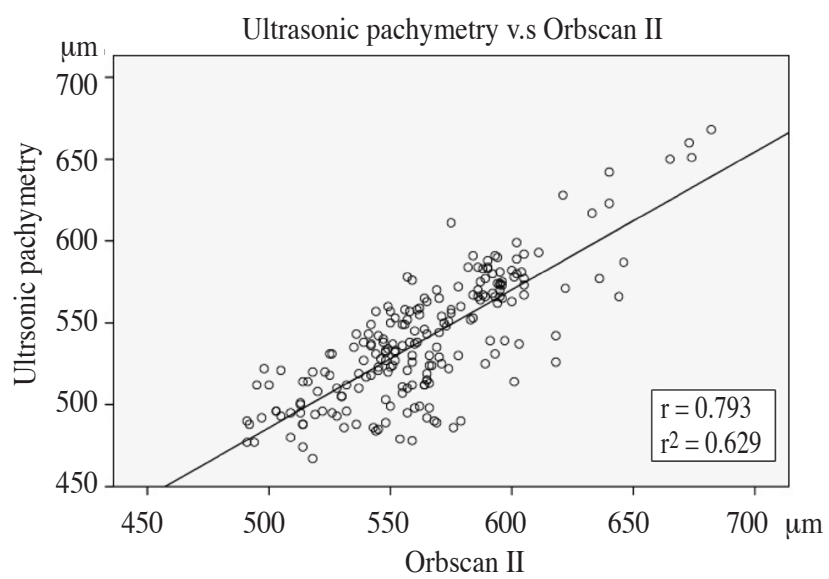

Fig. 1 Central corneal thickness with ultrasonic pachymetry versus Orbscan II system in all eyes. (Pearson correlation coefficient $(\mathrm{r})=0.793, p<0.001)$

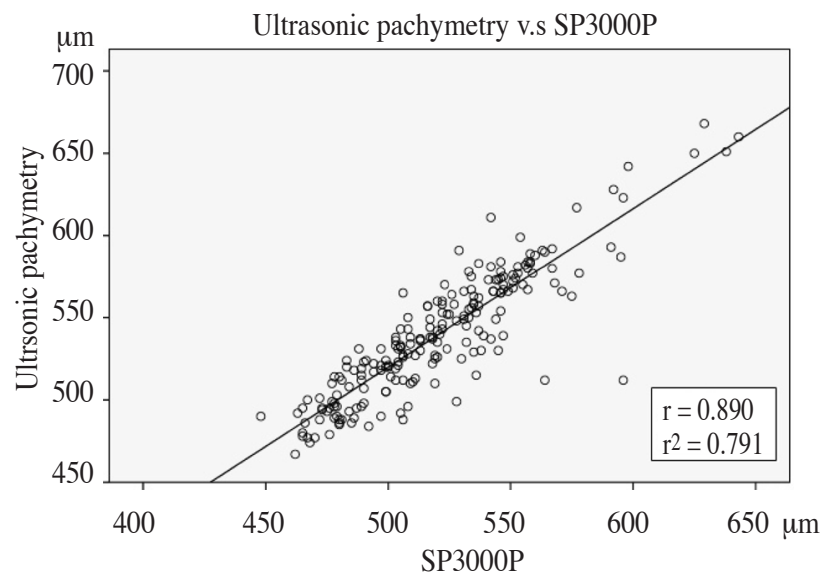

Fig. 2 Central corneal thickness with ultrasonic pachymetry versus SP3000P system in all eyes. (Pearson correlation coefficient $(\mathrm{r})=0.890, p<0.001)$

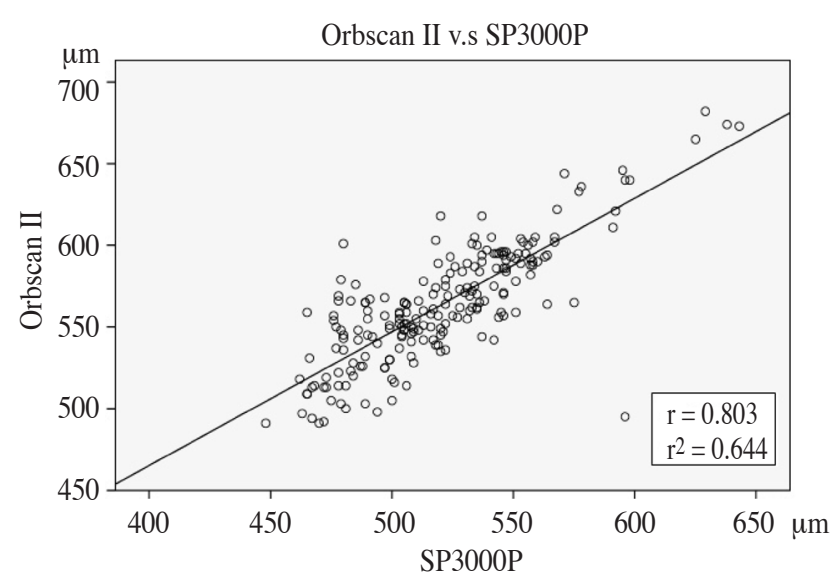

Fig. 3 Central corneal thickness with Orbscan II versus SP3000P system in all eyes. (Pearson correlation coefficient $(\mathrm{r})=0.803, p<0.001)$

seeking refractive surgery, African-American patients had thinner corneas than white patients, but there was no difference in CCT among white, Asian, and Hispanic patients. ${ }^{(23)}$ In our study, the mean (SD) CCT measured with ultrasonic pachymetry was $539.55(38.113) \mu \mathrm{m}$. This was similar to the results of the Singapore Malay study [mean (SD) 541.1 (35) $\mu \mathrm{m}]$. However, all our participants were glaucoma patients.

In our study, the CCT measured with Orbscan II [mean (SD) $563.63(35.867) \mu \mathrm{m}$ ] was significantly higher than that measured with ultrasonic pachymetry [mean (SD) $539.55(38.113) \mu \mathrm{m}](p<0.001)$. However, previous studies reported that CCT readings were overestimated with Orbscan II compared with ultrasonic pachymetry, ${ }^{(11,13,17,24)}$ and therefore, the acoustic factor 0.92 of Orbscan II was used to correct

Table 3. Pearson Correlation Coefficients of Central Corneal Thickness Measurements between Each Two Instruments

\begin{tabular}{|c|c|c|c|c|c|c|c|c|}
\hline & \multicolumn{2}{|c|}{$\begin{array}{c}\text { Total } \\
(\mathrm{n}=208)\end{array}$} & \multicolumn{2}{|c|}{$\begin{array}{l}\text { Thin CCT group } \\
\quad(\mathrm{n}=39)\end{array}$} & \multicolumn{2}{|c|}{$\begin{array}{l}\text { Intermediate CCT group } \\
\qquad(\mathrm{n}=141)\end{array}$} & \multicolumn{2}{|c|}{$\begin{array}{l}\text { Thick CCT group } \\
(\mathrm{n}=28)\end{array}$} \\
\hline & Correlation (r) & Sig. & Correlation (r) & Sig. & Correlation (r) & Sig. & Correlation (r) & Sig. \\
\hline US-Orbsccan II & 0.793 & $p<0.001$ & 0.139 & $p=0.4$ & 0.630 & $p<0.001$ & 0.868 & $p<0.001$ \\
\hline US- SP3000P & 0.890 & $p<0.001$ & 0.369 & $p=0.021$ & 0.709 & $p<0.001$ & 0.860 & $p<0.001$ \\
\hline Orbscan II- SP3000P & 0.803 & $p<0.001$ & 0.459 & $p=0.003$ & 0.594 & $p<0.001$ & 0.947 & $p<0.001$ \\
\hline
\end{tabular}

Abbreviations: US: ultrasonic pachymetry; CCT: central corneal thickness;

Groups were determined on the basis of the CCTmeasured by ultrasonic pachymetry as follows: Thin CCT group: $\leq 500 \mu \mathrm{m}$; Intemediate CCT group: $>500 \mu \mathrm{m}$ to $\leq 578 \mu \mathrm{m}$; Thick CCT group: $>578 \mu \mathrm{m}$. 
these data. On the contrary, other studies that used the acoustic factor 0.92 for Orbscan II reported underestimated readings. ${ }^{(25-28)}$ In our study, we used the acoustic factor 0.935 , and this could be why the CCT values measured with Orbscan II were high compared with the values measured with ultrasonic pachymetry. Nissen et al. reported that the ultrasonic probe can displace a 7 - to $40-\mu \mathrm{m}$ thick tear film, resulting in thinning of the epithelium. ${ }^{(29)}$

Overall, our study showed significantly good linear correlations between ultrasonic pachymetry and Orbscan II $(r=0.793, p<0.001)$ when 0.935 was used as the acoustic factor. Previous studies have also shown good linear correlations in normal human eyes. ${ }^{(30)}$ Kawanna et al. showed good linear correlations between ultrasonic pachymetry and Orbscan II in patients with keratoconus, but disproportionally lower readings with Orbscan II in thin corneas. ${ }^{(31)}$ In the thin CCT group, we found no significant linear correlations between ultrasonic pachymetry and Orbscan II ( $p=0.4)$, but in the intermediate and thick CCT groups, there were significant linear correlations between these 2 devices $(r=$ $0.630, p<0.001$ in intermediate group; $\mathrm{r}=0.868, p<$ 0.001 in thick CCT group). In our study, the $95 \%$ confidence interval for the difference between ultrasonic pachymetry and Orbscan II was -27.343 to 20.811. We could have used these data to predict conventional ultrasonic CCT if we had measured CCT only with Orbscan II.

The CCT measured with SP3000P [mean (SD), $520.32(35.179) \mu \mathrm{m}]$ was significantly lower than that measured with ultrasonic pachymetry [mean (SD), $539.55(38.113) \mu \mathrm{m}](p<0.001)$. Several studies have shown that CCT measured with noncontact specular microscopy is lower than that measured with ultrasonic pachymetry. ${ }^{(1,21,32)} \mathrm{Kawana}$ et al. showed that these differences occurred because these devices are based on different operating principles. In ultrasonic pachymetry, the exact posterior reflection point is not known; it may be located between Descemet's membrane and the anterior chamber. However, noncontact specular microscopy measurements depend on the reflection of light, while ultrasonic pachymetry measurements depend on the reflection of ultrasound from the anterior and posterior corneal surfaces. ${ }^{(21,31)}$

In our study, we could establish significantly good linear correlations between ultrasonic pachym- etry and SP3000P $(\mathrm{r}=0.893, p<0.001)$. In the 3 subgroups, there was a significant linear correlation between ultrasonic pachymetry and SP3000P ( $\mathrm{r}=$ $0.369, p=0.021$ in the thin CCT group; $\mathrm{r}=0.709$, $p<0.001$ in the intermediate group; and $\mathrm{r}=0.860$, $p<0.001$ in the thickest CCT group). These results were similar to those of previous studies conducted in patients who had undergone refractive surgery and those with keratoconus. ${ }^{(21,31)}$ In our study, the $95 \%$ confidence interval for the difference between ultrasonic pachymetry and SP3000P was 16.844 to 21.617.

In our study, we found that the difference in the CCT measured between Orbscan II and ultrasound was larger in, but the difference in the CCT measured between Orbscan II and ultrasound was less in the thin group. We thought this might be related to the tear film displacement when we performed ultrasonic pachymetry. Because the cornea is less rigid in thin corneas, the ultrasonic probe might induce more corneal displacement when this procedure is performed. ${ }^{(29)}$

Several studies have shown that corneal conditions may influence the optic system, especially in patients who have undergone refractive surgery. ${ }^{(33-35)}$ They also suggested that the formation of new collagen (type III collagen) and vacuoles filled with proteoglycan debris (keratin sulfate), observed in eyes with haze, result in a high degree of light scattering, which further increases the refractive index of the cornea and thus compromises optical pachymetry. In keratoconus, alteration in the regular orthogonal arrangement of the fibrils has also been reported. ${ }^{(36)}$ In our study, in order to ensure that a hazy cornea did not influence CCT measurements, we excluded participants who had poor corneal clarity. In these patients, CCT may be measured by conventional ultrasonic pachymetry.

\section{Conclusion}

CCT measurements are very important for glaucoma diagnosis. An increased CCT may give an artificially high IOP measurement, while a decreased CCT will result in an artificially low IOP measurement. In addition, people with a thin $\mathrm{CCT}$ are at a high risk of developing primary open-angle glaucoma. ${ }^{(6)}$ The gold standard method for CCT measurement is conventional ultrasonic pachymetry. However, noncontact procedures lower the risk of 
infection and corneal damage such as epithelial defects and corneal erosion. In this study, we compared the correlation of CCT measurements between each of the 3 devices in our hospital and showed significantly good linear correlations between them, especially in intermediate and thick CCT. These results will be helpful in predicting the relationship between IOP and CCT for the diagnosis and screening of glaucoma; even we used optic systems for CCT measurements.

\section{REFERENCES}

1. Brandt JD. Corneal thickness in glaucoma screening, diagnosis, and management. Curr Opin Ophthalmol 2004;15:85-9.

2. Doughty MJ, Zaman ML. Human corneal thickness and its impact on intraocular pressure measures: a review and meta-analysis approach. Surv Ophthalmol 2000;44:367408.

3. Ehlers N, Bramsen T, Sperling S. Applanatation tonometry and central corneal thickness. Acta Ophthalmol (Copenh.) 1975;53:34-43.

4. Whitacre MM, Stein RA, Hassanein K. The effect of corneal thickness on applanation tonometry. Am J Ophthalmol 1993;115:592-6.

5. Cioffi GA, Durcan FJ, Girkin CA, Gross RL, Netland PA, Samples JR, Samuelson TW, O'Connell SS, Keith Barton. 2008-2009 Basic and Clinical Science Course: Section 10: Glaucoma. San Francisco: American Academy of Ophthalmology, 2008:29.

6. Gordon MO, Beiser JA, Brandt JD, Heuer DK, Higginbotham EJ, Johnson CA, Keltner JL, Miller JP, Parrish II RK, Wilson MR, Kass MA; the Ocular Hypertension Treatment Study Group. The Ocular Hypertension Treatment Study: baseline factors that predict the onset of primary open-angle glaucoma. Arch Ophthalmol 2002;120:714-20.

7. Chauhan BC, Hutchison DM, LeBlanc RP, Artes PH, Nicolela MT. Central corneal thickness and progression of the visual filed and optic disc in glaucoma. Br J Ophthalmol 2005;89:1008-12.

8. Brown KE, Congdon NG. Corneal structure and biomechanics: impact on the diagnosis and management of glaucoma. Curr Opin Ophthalmol 2006;17:338-43.

9. Herndon LW, Weizer JS, Stinnett SS. Central corneal thickness as a risk factor for advanced glauaoma damage. Arch Ophthalmol 2004;122:17-21.

10. Wu B, Wong TY, Saw SM, Howard CU, Rosman M, Aung T. Effect of corneal arcus on central corneal thickness, intraocular pressure, and primary open-angle glaucoma: The Singapore Malay Eye Study. Arch Ophthalmol 2010;128:1455-61.
11. Yaylali V, Kaufman SC, Thompson HW. Corneal thickness measurements with the Orbscan Topography System and ultrasonic pachymetry. J Cataract Refract Surg 1997;23:1345-50.

12. Lattimore MR Jr, Kaupp S, Schallhorn S, Lewis R 4th. Orbscan pachymetry: implications of a repeated measures and diurnal variation analysis. Ophthalmology 1999;106: 977-81.

13. Liu Z, Huang AJ, Pflugfelder SC. Evaluation of corneal thickness and topography in normal eyes using the Orbscan corneal topography system. Br J Ophthalmol 1999;83:774-8.

14. Liu Z, Pflugfelder SC. Corneal thickness is reduced in dry eye. Cornea 1999;18:403-7.

15. Liu Z, Pflugfelder SC. The effects of long-term contact lens wear on corneal thickness, curvature, and surface regularity. Ophthalmology 2000;107:105-11.

16. Bovelle R, Kaufman SC, Thompson HW, Hamano H. Corneal thickness measurements with the Topcon SP2000P specular microscope and an ultrasound pachymeter. Arch Ophthalmol 1999;117:868-70.

17. Módis L Jr, Langenbucher A, Seitz B. Corneal thickness measurements with contact and noncontact specular microscopic and ultrasonic pachymetry. Am J Ophthalmol 2001;132:517-21.

18. Módis L Jr, Langenbucher A, Seitz B. Scanning-slit and specular microscopic pachymetry in comparison with ultrasonic determination of corneal thickness. Cornea 2001;20:711-4.

19. Javaloy J, Vidal MT, Villada JR, Artola A, Alió JL. Comparison of four corneal pachymetry techniques in corneal refractive surgery. J Refract Surg 2004;20:29-34.

20. Suzuki S, Oshika T, Oki K, Sakabe 1, Iwase A, Amano S, Araie M. Corneal thickness measurements using scanning-slit corneal topography and noncontact specular microscopy versus ultrasonic pachymetry. J Cataract Refract Surg 2003;29:1313-8.

21. Kawana K, Tokunaga T, Miyata K, Okamoto F, Kiuchi T, Oshika T. Comparison of corneal thickness measurements using Orbscan II, non-contact specular microscopy, and ultrasonic pachymetry in eyes after laser in situ keratomileusis. Br J Ophthalmol 2004;88:466-8.

22. Nemesure B, Wu SY, Hennis A, Leske MC. Corneal thickness and intraocular pressure in the Barbados eye studies. Arch Ophthalmol 2003;121:240-4.

23. Shimmyo M, Ross AJ, Moy A, Mostafavi R. Intraocular pressure, Goldmann applanation tension, corneal thickness, and corneal curvature in Caucasians, Asians, Hispanics, and African Americans. Am J Ophthalmol 2003;136:603-13.

24. Chakrabarti HS, Craig JP, Brahma A, Malik TY, McGhee $\mathrm{CN}$. Comparison of corneal thickness measurements using ultrasound and Orbscan slit-scanning topography in normal and post-LASIK eyes. J Cataract Refract Surg 2001;27:1823-8. 
25. Iskander NG, Anderson Penno E, Peters NT, Gimbel HV, Ferensowicz M. Accuracy of Orbscan pachymetry measurements and DHG ultrasound pachymetry in primary laser in situ keratomileusis and LASIK enhancement procedures. J Cataract Refract Surg 2001;27:681-5.

26. Rainer G, Petternel V, Findl O, Schmetterer L, Skorpik C, Luksch A, Drexler W. Comparison of ultrasoundpachymetry and partial coherence interferometry in the measurement of central corneal thickness. J Cataract Refract Surg 2002;28:2142-5.

27. Giraldez Fernandez MJ, Diaz Rey A, Cerviño A, YebraPimentel E. A comparison of two pachymetric systems: slit-scanning and ultrasonic. CLAO J 2002;28:221-3.

28. Prisant O, Calderon N, Chastang P, Gatinel D, HoangXuan T. Reliability of pachymetric measurements using Orbscan after excimer refractive surgery. Ophthalmology 2003;110:511-5.

29. Nissen J, Hjortdal JO, Ehlers N. A clinical comparison of optical and ultrasonic pachymetry. Acta Ophhalmol 1991;69:659-63.

30. Hashemi H, Roshani M, Mehravaran S, Parsafar H, Yadani K. Effect of corneal thickness on the agreement between ultrasonic and Orbscan II Pachymetry. J Cataract Refract Surg 2007;33:1694-700.
31. Kawana K, Miyata K, Tokunaga T, Kiuchi T, Hiraoka T, Oshika T. Central corneal thickness measurements using Orbscan II scanning slit topography, noncontact specular microscopy, and ultrasonic pachymetry in eyes with keratoconus. Cornea 2005;24:967-71.

32. Menassa N, Kaufmann C, Goggin M, Job OM, Bachmann LM, Thiel MA. Comparisn and reproducibility of corneal thickness and curvature readings obtained by the Galilei and the Orbscan II analysis system. J Cataract Refract Surg 2008;34:1742-7.

33. Prisant O, Calderon N, Chastang P, Gatinel D, HoangXuan T. Reliability of pachymetric measurements using Orbscan after excimer refractive surgery. Ophthalmology 2003;110:511-5.

34. Fakhry MA, Artola A, Belda JI, Ayala MJ, Alió JL. Comparison of corneal pachymetry using ultrasound and Orbscan II. J Cataract Refract Surg 2002;28:248-52.

35. Boscia F, La Tegola MG, Alessio G, Sborgia C. Accuracy of Orbscan optical pachymetry in corneas with haze. J Cataract Refract Surg 2002;28:253-8.

36. Daxer A, Fratzl P. Collagen fibril orientation in the human corneal stroma and its implication in keratoconus. Invest Ophthalmol Vis Sci 1997;38:121-9. 


\title{
在青光眼及疑似青光眼病人中，測量中心角膜厚度 在三種不同儀器 : 超音波厚度儀、角膜地圖儀 及角膜內皮細胞顯微鏡間之關聯性
}

\author{
歐宗和 賴盈州 鄧美琴
}

背 景: 青光眼及疑似青光眼病人中, 眼壓的測量會受到中心角膜厚度影響, 且中心角膜厚 度爲開放型隅角青光眼的危險因子。傳統超音波厚度儀 (pachymetry) 須接觸病人角 膜, 且所测數值和技術員經驗有影響; 目前一些非接觸式儀器, 如角膜地圖儀 (Orbscan II) 及角膜内皮細胞顯微鏡 (Specular Microscopy:SP3000P) 都可測得中心角膜 厚度, 本研究即比較這些非接觸式儀器和傳統超音波角膜厚度儀, 所測得之角膜厚 度的關聯性。

方 法: 總共有 104 位青光眼及疑似青光眼病人, 共 208 個眼睛, 以三種儀器測量中心角膜 厚度。在本研究中, 我們比較這些儀器間彼此的相關性。

結 果: 三種儀器中, 以角膜地圖儀所量測的中心角膜厚度平均值爲最大 (563.63 \pm 35.867 $\mu \mathrm{m})$ 。此三種儀器彼此間都有顯著意義的線性相關。以超音波厚度儀及角膜地圖儀所 量測的中心角膜厚度, 其線性相關係數爲 0.793 ; 超音波厚度儀及角膜内皮細胞顯微 鏡所量測的中心角膜厚度, 其線性相關係數爲 0.890 ; 角膜地圖儀及角膜内皮細胞顯 微鏡所量測的中心角膜厚度, 其線性相關係數爲 0.803 。

結 論: 在此研究中, 以三種儀器量測的中心角膜厚度, 彼此間都有顯著意義的線性相關。 在臨床上, 即使我們使用光學系統來量測, 這些結果也可幫助我們應用在評估青光 眼病人的中心角膜厚度。

(長庚醫誌 2012;35:255-62)

關鍵詞：中心角膜厚度, 超音波厚度儀, 角膜地圖儀, 角膜内皮細胞顯微鏡, 青光眼 